\title{
THE INFLUENCE OF VARIOUS REGIMENS OF TREATMENT ON THE LEVEL OF PROINFLAMMATORY CYTOKINE TNF-ALPHA IN INDUCED SPUTUM IN CASE OF AN EXACERBATION OF CHRONIC OBSTRUCTIVE PULMONARY DISEASE (COPD) IN PERSONS, WHO SUFFERED FROM PULMONARY TUBERCULOSIS
}

\author{
Ya.V. Ivanova
}

Abstract. The influence of various regimens of treatment of the regional (in induced sputum) level of proinflammatory cytokine TNF- $\alpha$ in patients with chronic obstructive pulmonary disease (COPD), who have suffered from pulmonary tuberculosis (PT), has been studied. An advantage of using a combined treatment of COPD exacerbation by means of $\beta_{2-}$ agonist and an anticholinergic preparation (berodual), and also doxofillin (aerofillin) for the purpose of correcting regional (endobronchial) imbalance of cytokine homeostasis is proved.

Key words: cytokine TNF- $\alpha$, chronic obstructive pulmonary disease, pulmonary tuberculosis.

Crimean State Medical University Named after S.I. Georgievsky (Simferopol)

Рецензент - проф. Л.Д. Тодоріко

Buk. Med. Herald. - 2013. - Vol. 17, № 1 (65). - P. 38-41

Надійшла до редакції 24.12.2012 року

(C) Я.В. Иванова, 2013

УДК 616.366-002+616-052+572.7+616.36

Н.Я. Іваночко

\section{СТАН ПЕРЕКИСНОГО ОКИСНЕННЯ ЛІПІДІВ У ОСІБ ЛІТНЬОГО ТА СТАРЕЧОГО ВІКУ, ХВОРИХ НА ГОСТРИЙ ХОЛЕЦИСТИТ}

ДВНЗ «Івано-Франківський національний медичний університет»

\begin{abstract}
Резюме. Проаналізовано результати хірургічного лікування 104 хворих на гострий та 50 хворих на хронічний калькульозний холецистит. Встановлено значні порушення в системі показників перекисного окиснення ліпідів у осіб літнього та старечого віку, хворих на гострий холецистит, що $є$ індикаторними критеріями
\end{abstract}

триваючого запального процесу в жовчному міхурі та вказують на необхідність медикаментозної корекції.

Ключові слова: гострий і хронічний калькульозний холецистит, особи літнього та старечого віку, перекисне окиснення ліпідів.

Жовчнокам'яна хвороба передбачає наявність холестазу різного ступеня, що, у свою чергу, сприяє активації системи порушеного процесу перекисного окиснення ліпідів, який корелює 3 процесами антиоксидантного захисту і поглиблює ступінь ендотоксемії, що володіє пошкоджуючою гепатоцелюлярною дією $[8,9]$.

Мета дослідження. Підвищити ефективність хірургічного лікування хворих на гострий калькульозний холецистит у осіб літнього та старечого віку, шляхом корекції синдрому ендогенної інтоксикації та функції печінки.

Матеріал і методи. Хворі на гострий і хронічний калькульозний холецистит(ХКХ) літнього та старечого віку. В основу клінічних, інструментальних і лабораторних досліджень покладено аналіз результатів лікування 154 осіб, у яких на тлі жовчнокам'яної хвороби виникли різні форми ГКХ. Серед обстежених 154 осіб чоловіків було 27 (17,53 \%), жінок - 127 (82,47\%). Вік пацієнтів літньої групи був у межах (60-74р.), а старечої 75-89 р. Осіб молодого віку - 19-45 років.

При надходженні пацієнтів до стаціонару проводили дослідження загального аналізу крові, загального аналізу сечі за загальноприйнятими методиками 33 - разовим контролем, а саме: до-, ністю зниженої реактивності організму та супутньою патологією [8]. 
та післяопераційного лікування (3-5-та, 7-10-та доба). Для з'ясування адекватності застосованого лікування проводили кількісне визначення ступеня інтоксикації, використовуючи лейкоцитарний індекс інтоксикації (ЛІІ) Я.Я. Кальф - Каліфа, у нормі 0,89 $\pm 0,20$ у.о., стан процесів перекисного окиснення ліпідів - використовували тест 3 тіобарбітуровою кислотою в модифікації Н. Коробейникова. Принцип методу базується на тому, що при нагріванні в кислому середовищі частина продуктів перекисного окиснення ліпідів розкладається з утворенням малонового альдегіду(МА), який при взаємодії з двома молекулами тіобарбітурової кислоти утворює забарвлений комплекс. У нормі рівень МА 3,507 $\pm 0,006$ нмоль/мл.

Обстеження та лікування вказаних груп хворих відбувалося на базі хірургічного відділення центральної міської клінічної лікарні м. ІваноФранківська.

Усіх пацієнтів розподілено на наступні клінічні групи:

I група - 54 особи літнього і старечого віку 3 діагнозом ГКХ;

II група - 50 осіб літнього і старечого віку 3 діагнозом XКХ; ГКХ

III група - 50 осіб молодого віку з діагнозом

Найбільшу частину хворих на калькульозний холецистит (КХ) склали пацієнти старших вікових груп (67,5 \%). Тривалість захворювання на жовчнокам'яну хворобу становила від 1 до 10 років і більше. Серед групи осіб, старших 60 років, вперше захворіли лише $2 \%$, в інших „камененосійство” тривало від 1 до 10 років (98,7 \%). У 65,4 \% хворих напади ГХ виникали протягом 5-10 років. Серед супровідної патології найчастіше спостерігали ішемічну хворобу серця (65,58 \%), дифузний міокардіосклероз (63,64 \%), гіпертонічну хворобу $(29,87 \%)$, ожиріння $(8,18 \%)$, варикозне розширення підшкірних вен обох нижніх кінцівок $(20,13 \%)$, захворювання шлунково-кишкового тракту (11,2\%). Госпіталізовано 83,3 \% осіб після 24 год, і лише 16,66 \% доправлено до 24 год 3 моменту захворювання. При надходженні до стаціонару всім пацієнтам призначали консервативну терапію, спрямовану на ліквідацію запального процесу, лікування супровідної патології. Операції проводили шляхом виконання лапароскопічної та лапаротомічної (конверсія) холецистектомії. У групі осіб літнього та старечого віку екстрено прооперовано $(7,4 \%)$; терміново - (14,8 \%); невідкладно $(20,4 \%)$; вимушено - (12,9 \%); планово $(44,4 \%)$ і загалом до 72 годин прооперовано $(55,6 \%)$.

У II клінічній групі всі пацієнти були прооперовані планово (100\%), тому що надійшли до стаціонару хірургічного відділення в стані повної клінічної ремісії на заплановане хірургічне оздоровлення.

У III клінічній групі: екстрено прооперовано $16,0 \%$; терміново - 30,0 \%; невідкладно - 20,0 \%; вимушено - 16,0 \%; планово - 18,0 \% і загалом до 72 годин прооперовано $82 \%$.

При проведенні операційного втручання пацієнтів першої клінічної групи виявлено флегмонозний холецистит у $46,3 \%$, гангренозний - у $53,7 \%$ осіб. У ІІІ клінічній групі флегмонозний холецистит відзначено у $18,0 \%$; гангренозний - у $16,0 \%$; катаральний - у 66,0 \%.

Накопичення продуктів ліпопероксидації в пацієнтів I клінічної групи було максимальним, про що свідчило збільшення дієнових кон'югат (ДК) і малонового альдегіду (МА). Рівень МА до оперативного лікування складав в середньому $5,72 \pm 0,13$ нмоль/мл, що перевищувало норму на

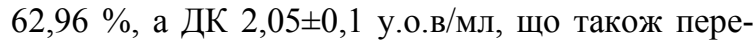
вищувало норму на 41,37 \%. Після проведеного операційного лікування показники мали тенденцію до зменшення і на 3-5-ту добу з моменту проведеної операції знизилися, відповідно на $33,4 \%$ та 20,48 \%, але до норми не повертались. На 7-10-ту добу показники наблизились до нормальних величин; рівень МА перевищував норму лише на 4,65 \%, а ДК - на 7,59\%. Отже, рівень ДК мав тенденцію до зростання разом з МА до операційного лікування та зменшення після операції.

При дослідженні пацієнтів II клінічної групи виявлено незначну активацію стану перекисного окиснення ліпідів у вигляді наростання МА та ДК.

При доставленні до стаціонару рівень МК та ДК перевищував норму на $13,48 \%$ та 25,52 \%. На 3-5-ту добу після оперативного втручання дані показники зменшилися на $0,51 \%$ та 13,77 \%. Після проведеного лікування на 7-10-ту добу рівень МА зменшився на 11,81 \%, ДК - на 19,78 \%.

У третій клінічній групі рівень МА та ДК становив до операційного втручання 4,002 $\pm 0,008$ нмоль/мл та 2,076 $\pm 0,04$ у.о в/1 мл, що переважало норму на $14,11 \%$ та 4,17\%.

Внаслідок проведеного операційного лікування на 3-5-ту добу рівень МА та ДК знизився до $3,75 \pm 0,090$ нмоль/мл та $1,64 \pm 0,042$ у.о.в/мл, тобто $6,29 \%$ та $21,01 \%$ і на 7-10-ту добу від проведеного лікування зменшились на 12,29 \% та 29,68 \% і порівняно 3 нормою на 7-10-ту добу рівень МА та ДК практично стабілізувався.

Отримані дані свідчать про значне порушення окиснювально-відновних процесів в організмі хворих на ГКХ у літньому та старечому віці, де проходить більш виражена активізація ПОЛ, ніж у пацієнтів даної вікової групи при ХКХ та ГКХ в осіб молодого віку. Очевидно, це відбувається тому, що в старечому і літньому віці суттєво змінений метаболізм ліпідів.

У І групі пацієнтів при госпіталізації рівень МА перевищував норму на 62,96 \%, а ДК- на $41,37 \%$ i зменшувався на 3-5-ту добу до 3,81 $\pm 0,019$ нмоль/мл, а на 7-10-ту добу перевищував норму лише на 4,65 \%. Рівень ДК становив на 3-5-ту добу післяопераційного періоду $1,63 \pm 0,08$ у.о./ мл та на 7-10-ту добу перевищував 
норму лише на 7,59 \%. Це свідчить про те, що у хворих на 3-5-ту добу стабілізації запального процесу ще немає, а на 7-10-ту добу є значна тенденція до його затихання. Достовірна різниця до вихідного рівня показника МА та ДК у першій групі мала місце як на 3-5-ту, так і на 7-10-ту добу, а рівень МА і ДК перевищував норму до лікування відповідно в 1,63 раза та 1,45 раза.

У II клінічній групі відмічена незначна активація процесів ПОЛ на фоні хронічного запального процесу в жовчному міхурі, що можна пояснити вищими компенсаторними процесами організму даної вікової групи у зв'язку 3 тривалістю захворювання та, відповідно, вищими процесами відновлювального характеру. При госпіталізації їх рівні перевищували норму: МА - на 13,48 \%, а ДК - на 25,52 \%.

У даній групі спостерігалася недостовірна різниця між показниками на 3-5-ту добу післяопераційного періоду та вихідним рівнем показника МА, який мав тенденцію до зменшення. Достовірна різниця показників ДК по відношенню до вихідного рівня мала місце на 3-5-ту добу та на 7-10-ту добу.

У ІІІ клінічній групі рівень МА та ДК переважав норму на $14,11 \%$ та 43,17\%. У процесі лікування зменшувався плавно, достовірна різниця по відношенню до вихідного рівня і в процесі лікування спостерігалася на 3-5-ту добу та 7-10ту добу лікування.

Отже, рівень МА в пацієнтів I клінічної групи був більший при шпиталізації, порівняно 3 пацієнтами другої клінічної групи, на 49,48 \%, а від показника в третій клінічній групі - більший на $48,85 \%$.

Відносно ДК - рівень їх у першій клінічній групі був більший при надходженні, порівняно 3 другою клінічною групою на 15,85 \%, а від показника третьої клінічної групи був навпаки, меншим лише на $1,8 \%$.

На 3-5-ту добу післяопераційного періоду рівень МА в I клінічній групі був більшим за норму на 8,64 \% i, відповідно, меншим за показник у II групі - на 4,28 \%, та більшим за рівень у III групі на 1,71 \%. Рівень ДК був більшим за такий у II групі на 4,13 \% і меншим, ніж у III групі - на 0,69 \%. На 7-10-ту добу рівень МА в I клінічній групі перевищував норму на 4,65 \% і більший за такий у II і III групах на 4,56 \%, а рівень ДК вищий від рівня за показник у II та III групах - на 6,9%.

Таким чином, активація процесів перекисного окиснення ліпідів значною мірою відображається на зростанні показника величини МА та ДК, що пов'язано з перебігом запального процесу. Використаний як об'єктивний критерій для оцінки ступеня ендогенної інтоксикації рівень лейкоцитарного індексу інтоксикації показав, що в першій групі осіб старших вікових категорій вихідний рівень склав $3,97 \pm 0,14$ у.о. і був підвищеним порівняно 3 нормою у 4,5 раза, на 3-5-й день після операційного лікування ЛІІ зменшився і становив $3,63 \pm 0,18$ у.о., а на термін виписки (7- 10-та доба) знизився до 2,62 $\pm 0,22$ у.о. і залишався більшим за норму в 2,9 раза. У другій групі хворих показник ЛІІ при госпіталізації складав $2,41 \pm 0,16$ у.о. - перевищують норму у 2,8 раза $\mathrm{i}$ на 7-10-ту добу - 1,62 $\pm 0,25$ у.о., що залишалося вищим за норму лише в 1,8 раза. У третій групі ЛІІ був вищим за норму до лікування у 3,8 раза, на 7-10-ту добу після лікування залишався більшим від норми у 2,7 раза.

Значне підвищення рівня ЛІІ у хворих вказує на реакцію організму на пошкоджуючу дію ендотоксикозу і було найбільш виражене в осіб старших вікових груп з ускладненим перебігом ГКХ (флегмонозний, гангренозний), меншою мірою у третій групі, яку складали особи молодого віку 3 неускладненим перебігом ГКХ, і найменше, - у другій групі хворих на ХКХ. Високі показники ЛІІ в осіб першої групи, що утримувалися і після лікування підтверджують, що для стабілізації його потрібен досить значний період часу лікування і вказують на неспроможність пацієнтів даної групи протистояти ендоінтоксикації. Вірогідність показників по відношенню до вихідного рівня спостерігалась у всіх групах на 7-10-ту добу післяопераційного лікування.

Порушення рівноваги між швидкістю утворення активних форм кисню та їх утилізації призводить до посилення процесів перекисного окиснення ліпідів, що зумовлює порушення структури і відповідно функції біологічних мембран. Велике значення має нормалізація функціонального стану гепатоцитів, яке $\epsilon$ важливим ланцюгом у детоксикаційних метаболічних перетвореннях, що ми супутньо проводимо в доопераційній підготовці пацієнтів різних вікових груп із ГКХ, застосовуючи розчини кристалоїдів (електроліти, глюкозу), а також середники гепатопротекторної дії, що дає можливість покращити перебіг післяопераційного періоду в пацієнтів із даною патологією. Таким чином, своєчасне визначення необхідності та термінів операційного втручання, характеру доопераційної підготовки та методу операційного лікування сприяє значно кращому результату післяопераційного періоду. Особливо це стосується пацієнтів старших вікових груп, у яких існують розбіжності в питанні термінів планового операційного втручання після затихання запального процесу в жовчному міхурі.

\section{Висновки}

1. Клініка гострого калькульозного холециститу в пацієнтів старших вікових груп на фоні супровідної патології характеризується малою вираженістю симптомів, в'ялим перебігом, неманіфестаційністю скарг, вираженими ознаками ендоінтоксикації і більш частими, порівняно 3 пацієнтами молодої вікової групи, деструкційними формами. Кількість пацієнтів цієї категорії становить 67,5 \% всіх доставлених до клініки за останні п'ять років.

2. У хворих на гострий калькульозний холецистит літнього та старечого віку настає значна активація процесів перекисного окиснення ліпі- 
дів, що супроводжується зростанням у крові концентрації продуктів ліпопероксидації - рівень концентрації малонового альдегіду перевищує норму на $62,96 \%(5,72 \pm 0,13$ нмоль/мл), а дієнових кон'ю-

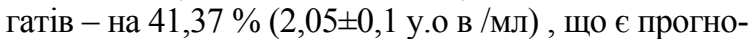
стично несприятливим критерієм і вказує на тривалий запальний процес у жовчному міхурі.

Перспективи подальших досліджень. Виявлені порушення можуть бути перспективними в обгрунтуванні дослідження функціонального стану печінки у хворих на гострий калькульозний холецистит літнього та старечого віку та розробки додаткового патогенетичного лікування із застосуванням препаратів антиоксидантної та гепатопротекторної дії.

\section{Література}

1. Андрющенко В.П. Поодинокі, численні, поєднані ускладнення гострого холециститу та можливості їх корекції з використанням загальноприйнятих і сучасних хірургічних технологій / В.П. Андрущенко, В.I. Прикупенко, Д.В. Андрющенко // Клін. хірургія. - 2004. № 4-5. - С. 39.

2. Бобров О.Е. О необходимости единых взглядов на классификацию хирургических вмешательств у больных острым холецистом / О.Е. Бобров, Ю.С. Семенюк / Хірургія України. - 2003. - № 2. - С. 97-98.

3. Бучнев В.I. Переваги мінілапаротомії при хірургічному лікуванні хворих гострим каль- кульозним холециститом на фоні хронічних обструктивних захворювань легень / В.І. Бучнев // Наук. вісн. Ужгородського ун-ту., серія „Медицина”. - 2001. - № 14. - С. 63-64.

4. Бондаренко М.М. Діагностичні можливості допплерівського ультразвукового дослідження у пацієнтів 3 жовчнокам'яною хворобою, ускладненою обтураційною жовтяницею / М.М. Бондаренко, В.П. Кришень, В.В. Задорожний // Клін. хірургія. - 2007. - № 2-3. - С. 66.

5. Васильєв О.О. Профілактика ускладнень лапароскопічної холецистектомії у хворих на гострий холецистит / О.О. Васильєв // Шпит. хірургія. - 2001. - № 2. - С. 22-24.

6. Выбор хирургической тактики у больных с обтурационной желтухой и высоким риском возникновения полиорганной недостаточности / Н.Н. Велигоцкий, А.А. Велигоцкий [и др.] // Клін. хірургія. - 2001. - № 7. - С. 10-13.

7. Гордієнко В.М. Особливості запальної реакції при хронічному холециститі / В.М. Гордієнко // Клін. хірургія. - 2004. - № 4-5. - С. 10.

8. Горобець Р.М. Прогнозування ускладнень калькульозного холециститу / Р.М. Горобець // Клін. хірургія. - 2004. - № 4. - С. 11.

9. Горобець Р.М. Синдром ендогенної інтоксикації при ускладненому гострому холециститі / Р.М. Горобець // Клін. хірургія. - 2004. № 3. - C. 14-15.

\section{СОСТОЯНИЕ ПЕРОКСИДНОГО ОКИСЛЕНИЯ ЛИПИДОВ У ЛИЦ ПРЕКЛОННОГО И СТАРЧЕСКОГО ВОЗРАСТА, БОЛЬНЫХ ОСТРЫМ ХОЛЕЦИСТИТОМ}

\section{Н.Я. Иваночко}

Резюме. Проанализировано результаты хирургического лечения 104 больных с острым и 50 больных с хроническим калькулезным холециститом. Обнаружены значительные отклонения в системе показателей пероксидного окисления липидов у лиц преклонного и старческого возраста, больных острым холециститом, которые являются индикаторными критериями наличия воспалительного процесса в желчном пузыре и указывают на необходимость медикаментозной коррекции.

Ключевые слова: острый и хронический калькулезный холецистит, больные преклонного и старческого возраста, пероксидное окисление липидов.

\section{THE STATE OF LIPID PEROXIDATION IN ELDERLY AND SENILE PERSONS, SUFFERING FROM ACUTE CHOLECYSTITIS}

\section{N.Y. Ivanochko}

Abstract. The results of surgical treatment of 104 patients with acute and 50 patients with chronic calculous cholecystitis have been analyzed. Considerable violations have been revealed in the system of the indices of lipid peroxidation in persons of elderly and senile age, that are indicative criteria of an inflammatory process in the gallbladder and point out to the necessity of medicamental correction.

Key words: acute and chronic calculous cholecystitis, patients of alderly and senile age, lipid peroxidation.

SHEE «National Medical University» (Ivano- Frankivs'k)

Рецензент - проф. В.П. Польовий

Buk. Med. Herald. - 2013. - Vol. 17, № 1 (65). - P. 41-44

Надійшла до редакції 15.11.2012 року

(C) Н.Я. Іваночко, 2013 